\title{
Manufacturing Company Debt and Its Moderation Effect on Capital Structure: The Case of Public Company in Indonesia
}

\author{
Isti Pujihastuti ${ }^{1, *}$, Ujang Maman ${ }^{2}$, Iwan Aminudin ${ }^{2}$, Kuncoro Hadi $^{3}$, Hanny Nurlatifah ${ }^{3}$, \\ Rusdiono Mukri ${ }^{4}$, Sudirah ${ }^{5}$ \\ ${ }^{1}$ Department of Management, Faculty of Economy and Business, Universitas Islam “45” Bekasi, Indonesia \\ ${ }^{2}$ Agribusiness Post Graduate Program, Faculty of Science and Technology, Universitas Islam Negeri Syarif Hidayatullah Jakarta, \\ Indonesia \\ ${ }^{3}$ Department of Management, Faculty of Economy and Business, University of Al-azhar Indonesia, Indonesia \\ ${ }^{4}$ Sahid Islamic Entrepreneurial University, Indonesia \\ ${ }^{5}$ Faculty of Law, Social and Political Science, Universitas Terbuka Indonesia, Indonesia
}

Received October 19, 2021; Revised January 11, 2022; Accepted February 8, 2022

\section{Cite This Paper in the following Citation Styles}

(a): [1] Isti Pujihastuti, Ujang Maman, Iwan Aminudin, Kuncoro Hadi, Hanny Nurlatifah, Rusdiono Mukri, Sudirah, "Manufacturing Company Debt and Its Moderation Effect on Capital Structure: The Case of Public Company in Indonesia," Universal Journal of Accounting and Finance, Vol. 10, No. 2, pp. 411 - 424, 2022. DOI: 10.13189/ujaf.2022.100205.

(b): Isti Pujihastuti, Ujang Maman, Iwan Aminudin, Kuncoro Hadi, Hanny Nurlatifah, Rusdiono Mukri, Sudirah (2022). Manufacturing Company Debt and Its Moderation Effect on Capital Structure: The Case of Public Company in Indonesia. Universal Journal of Accounting and Finance, 10(2), 411 - 424. DOI: 10.13189/ujaf.2022.100205.

Copyright $\bigcirc 2022$ by authors, all rights reserved. Authors agree that this article remains permanently open access under the terms of the Creative Commons Attribution License 4.0 International License

Abstract Debt is one of the important sources of fund for Indonesian companies. The previous research of manufacturing companies listed on Indonesia Stock Exchange (IDX) in 2015-2017 indicated debt to equity ratio is $111 \%$. The debt could probably cause disadvantages. There are requirements from external parties when companies request sources of funds, especially when conducting Initial Public Offerings (IPOs). There should also be debt covenants between company and debtor. However, the proper debt management will have a positive effect on capital structure. Therefore, this research aims to explore the effect of long-term debt (LTD), fixed assets (FA), earnings per share (EPS) and net income (NI) on capital structure (CS), assuming that LTD will moderate the effect of FA, EPS, and NI on equity. The research sample is 32 of manufacturing companies that conducted IPOs on IDX in period of 2018-2020, which were purposively taken based on the criteria of publishing annual financial report and having complete data needed in this research. Fortunately, the research found 11 companies for 2018; 9 companies for 2019; and 12 companies for 2020. The multiple linear regressions with cross data section show NI, FA, and EPS affect CS significantly; while LTD does not influence CS. However, the LTD significantly quasi-moderates the effect of FA on CS. While the LTD significantly moderates purely the effect of NI on CS. Therefore, the companies should manage the NI for investment in FA and increase the effectiveness of LTD's management in optimizing capital structure.

Keywords Initial Public Offering, Company Debt, Fixed Assets, Earnings Per Share, Net Income, Equity

\section{Introduction}

Sources of company funds can ensure the implementation of effective organizational processes. On the other hand, the lack of funds has a serious impact on the company, the production process falters, the company's sales are hampered, then the company's goals as a profit-oriented institution cannot be achieved, and the company's profits decline. It is clear that on a micro scale 
the manufacturing companies should achieve internal efficiencies. It is important because the manufacturing companies are a vital sector in contributing to the economic development and employment [15].

The manufacturing industry involves processing in making the final product so that the added value provided looks more real. The manufacturing process, which is a special feature of the manufacturing industry, requires quite a lot of investment, both for factory installation and investment in raw materials, semi-finished and finished goods.

All of these investments are funded from corporate sources. The sources of funds can be in the form of internal or external funder.

The external funding in the form of debt - the current as well the long-term debt -- is quite important and dominant as a source of funding for the manufacturing companies in Indonesia. The previous research about manufacturing companies listed in Indonesian Stock Exchange (IDX) in 2015-2017 indicated the average debt to asset ratio (DER) in three years was $45 \%$, while the average of debt to-equity ratio (DER) was strongly high, reached $111 \%$ [25]. In this context, the operational of manufacturing companies in Indonesia still depends upon the debt. The main advantage of financing with debt is the existence of a tax shield due to interest payments [9]. But it is further stated that the cost of debt is closely related to: (1) increase probability of bankruptcy; (2) the agency costs from creditors could probably limit the company's actions; 3) costs that arise because of information asymmetry owned more by managers than investors.

However, in line with the pecking order theory [26], the manufacturing companies in Indonesia try to meet their funding needs by the internal sources, from the owners or shareholders. To meet the needs of funds through the internal public offering (IPO) proses is popular within the manufacturing companies listed in IDX. The IPOs have been quite attractive to company as new sources of funding available in large quantities, and to improve the company image as well as to increase the company value [11].

On the other hand, the investors are not just buying IPO shares but will pay attention to the company's performance, for example the company's financial performance by looking at the company's financial condition after the IPO process. The issuers must continuously maintain their performance so that there is always a positive impact of company policies on shares of the stock exchange. The positive signals of course will have an impact on investors' expectations. Even though there is good supervision from the government, the investors must always be careful regarding the proper use of funds obtained from the IPO process. With the flow of fresh funds to the company, it should have a significant impact on the better of company's equity. The experience of London Stock Exchange (LSE) indicates the IPO has a significant effect on the survival of the firm [13].
Therefore, the better capital structure which is represented by equity is quite important, and it is strongly influenced by net income, earning per share, and fixed asset. The fund management after the IPO process should have a strong impact on the performance of capital structure. The debt management - if the companies still depend upon the debt - should get attention. The external funding could become the source of investment in fixed asset, and consequently it will properly contribute to the performance of capital structure of public company. Mahdaleta et al. [6] states that the capital structure includes relatively varied equity and debt which consist of various funding sources.

Based on the above description, the question is in what extent the manufacturing industries in Indonesia still depend on the external fund in the form of deb in addition to the IPO process? How far the long-term debt - if it is still dominant -- has a better impact on the equity? The long-term debt, earning per share, and net income are properly assumed as a significant source for the investment on the fixed asset, which finally will affect the equity. This study aims to answer the above question, as well as to identify the effect of long-term debt, fixed assets, earnings per share and net income on the company's equity. For more detail, this research questions whether debt moderates the effect of fixed assets on the company's equity. For this aim, the research was conducted in the manufacturing industry that carried out IPO process during 2018-2020.

This research is valuable because the financial performance is a barometer of the success of profit-oriented companies. The companies should manage the internal and the external funding properly to perform the capital structure as to achieve the goals of company. On the other hand, the investors need to pay attention to a more specific company's financial performance to make a decision in investment process.

\section{Framework Theory}

\subsection{The Finance of Manufacturing Company}

The development of a company needs to be considered continuously, and to acquire a reliable measure, the company's financial statements are quite important. The company's performance is used as a tool to determine whether the company is experiencing development or vice versa. The company's performance measure is one way to assess the company's performance which is needed to determine the company's success in achieving its goals. Financial statement analysis can be done by calculating financial ratios. The financial ratio analysis is an instrument to show changes in the company's financial condition. By this financial ratio analysis, the company's strengths and weaknesses in the financial sector can be 
identified. The financial ratios can be applied to determine the stock and company value as well as to predict the probability of bankruptcy $[20 ; 3]$. This analysis can also be used as an early warning system to identify a decline in the company's financial condition which results in uncertainty.

The business line of a manufacturing company is processing raw materials into finished goods or ready-to-use goods that can be directly marketed. By these characteristics, the manufacturing company has specificity, in which the manufacturing process requires assets as a mean of production with a fairly large investment value compared to other types of companies. It is clear that the asset value of manufacturing companies tends to be large. On the other hand, the funding is also quite large, which can be met by internal sources of funds (equity) or from outside the company.

The equity is a component of the company's capital structure. According to Mahdaleta et al. [6], the capital structure is the proportion of the use of short-term debt, long-term debt, preferred stock and common stock used to fund the company. Panggiarti et al. [8] suggest the importance of equity, in which the manufacturing companies should keep equity efficient so as to limit debt financing. Because there are also some companies that have problems with debt financing, causing the company to experience equity deficiency.

\subsection{The Theory of Company Capital Structure}

There are two broad views of the theory of capital structure. First, the view is that capital structure does not affect firm value. This assumption was expressed in 1958 by Franco Modigliani and Merton H Miller, hereinafter referred to as the MM theory [9]. However, this assumption is relaxed to allow for a balance between the benefits and costs arising from the use of debt funds. This allows the influence of capital structure on firm value as the second view which states clearly that capital structure affects firm value.

The development of this theory is in line with the view of the trade-off theory [16], which the debt can be added continuously as long as the benefits are still greater than the sacrifices caused by debt. On the other hand, if the sacrifice due to this debt is greater, the company should not add the debt. The trade-off theory in capital structure explains the differences in the targeted capital structure among companies. This theory states that the implication of greater debt means less risk for lenders. In addition, the company's ability to pay interest indicates a better capacity or credibility of the company. Therefore, the company can choose an optimal capital structure, in which it occurs when the value of the company reaches its maximum point, which coincides with the occurrence of minimal capital costs.

The capital structure, fortunately, tends to shift due to various reasons, so the most feasible way is to adhere to a targeted capital structure. The results of Sartono's research [1] on the policies of financial managers of public companies on the Indonesia Stock Exchange indicated that the target capital structure is something that is flexible for these managers, so that when managers are challenged with very attractive investments, they will carry out the investment project. The same research is found in Yordanian industrial firm, which financial flexibility plays an important role on determining the financing decisions [22]. This means that managers tend to deviate from the target capital structure; and the debts are the main factor for this deviation.

The deviation of capital structure should have to be reported properly to the company stakeholders. However, when the market is efficient, then information will be fairly distributed to all stakeholders. But, the information asymmetry could probably appear, which underlies the signaling theory [5]. In the case of an inefficient market, the company managers have more information than investors, even when the information is the same there is still the possibility of different perceptions [21]. Then, the investors who do not like the risk-reward of a security will sell it in spite of in a lower price. This will of course have an impact on the finances and the capital structure of the related company, including the manufacturing companies.

Furthermore, in this context, the agency theory should be considered that the company is an entity that is not a single one. Normatively, management should act for the welfare of the owner. But what managers need to remember is that they are stakeholders as well. A company as a legal institution involves a fairly complex process in which there is a conflict between individual goals and organizational goals, which of course should be resolved in the form of a contract agreed by the parties. All company stakeholders (shareholders, managers, creditors) have a single goal to create value. Meanwhile, there are differences in the interests of the various stakeholders. Thus, good corporate governance must realize that they should do nothing but an effort to regulate executive power in decision making in order to ensure the common interest, not only the interests of certain groups but all company stakeholders [21]. In this context, referring to Nugroho et al [2], the corporate governance and competition should have a close relationship with decision of company investment and capital structure.

Furthermore, there is a heated debate about the company's capital structure and the factors that influence it, in addition to long-term debt. The view of pecking order theory in this discussion could not be left behind. The companies that have high liquidity will tend not to use debt financing because they have large funds for internal funding. The pecking order theory emphasizes, debt (short as well as the long-term debt) is not prioritized in the company capital structure, and in contrary the company will prefer the internal source of funds [14].

Previously, Gitman and Zutter [9] state that pecking 
order theory involves two concepts of funding sources, namely internal capital and external capital. The Internal capital refers to cash flow generated internally, more generally in the form of periodic income that is not distributed to shareholders; while the external capital is obtained from outside the company, namely from debt to creditors or from equity, namely new shareholders. According to Pecking order theory, which is also known as hierarchical financing, the company will follow a certain hierarchy, starting with the source with the lowest risk, namely retained earnings, debt, and then the issuance of new shares. Retained earnings are the portion of profits that are not distributed to shareholders. The recent research which takes 38 sample of family company listed in Indonesia Stock Exchange indicates the view of pecking order theory is strongly popular within the family firms [14].

The above discussion encourages us to explore more about the factors influencing the company capital structure. Fixed asset, net income, and earning per share could hypothetically be predicted as the main factors for the equity. The recent research findings of Mujiatun et al [18] support us to explain this question, in which the profitability and asset structure has a significant effect on capital structure. The role of debt (long term debt) is more interesting to explore, because it is possible for the effective and prudent manager to manage the long-term debt to become fixed asset. Therefore, this research is interested in exploring the interaction between long term debt, fixed asset, net income and earnings per share and its influence on the capital structure of manufacturing company. But, fortunately, relating with the IPO process, the capital structure in this study is more emphasized only on equity (own capital).

\section{Framework Analysis and Hypothesis}

\subsection{Framework Analysis}

The IPOs with all their phenomena always grab the public's attention. For example, in terms of the process which is quite time-consuming until the final result, potential investors are always waiting for the possibility of take profit in the primary market, as well as by issuers who hope for the success of the IPO process. The success of the IPO process has many implications for issuers, not only in terms of obtaining fresh funds for their equity but also the issuer's credibility in the eyes of the public.

Actually, there are many variables that affect the company's capital structure, which in this study is represented by equity. However, based on the above discussed theories, this research observes merely several independent variables, namely long-term debt (LTD), fixed assets (FA), earnings per share (EPS) and net income (NI), which the LTD takes a position of a moderating variable. Thus, the research framework analysis is described in Figure 1.

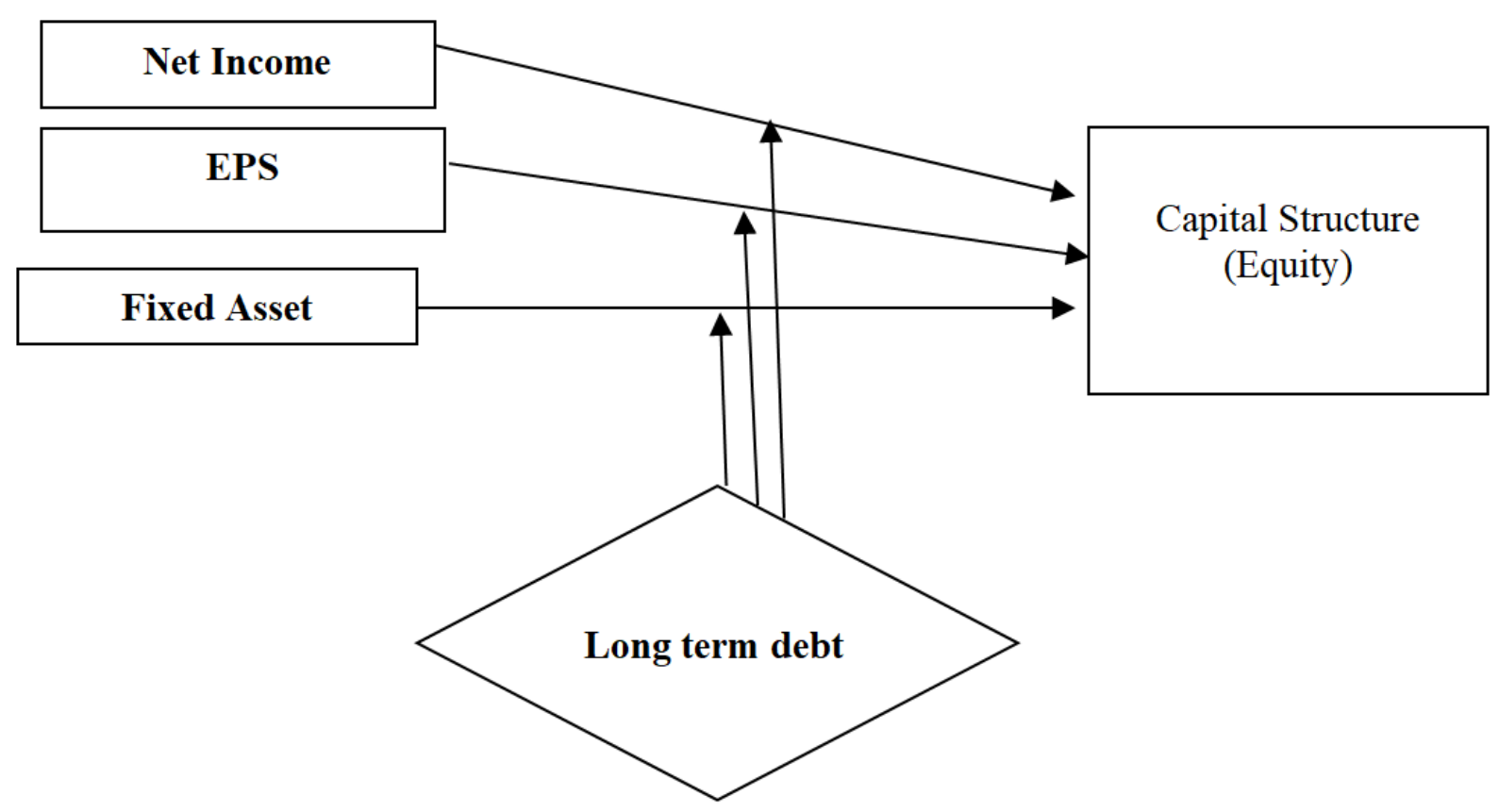

Figure 1. Research Framework 


\subsection{The Research Hypothesis}

\subsubsection{The Effect of Debt and Assets on Capital Structure}

Increasing investment of course requires a source of funds, as well as investment in fixed assets. On the other hand, increasing debt will increase the company's capital and vice versa. Gitman and Zutter [9] state that there is a general trend that profitable companies are more likely to borrow less than non-profitable companies. Therefore, the lower the long-term debt is, the smaller the company's capital will be. Meanwhile, the long-term debt requires fixed assets as collateral for debt. In this context, Aryani et al. [10] found the positive and significant effect of asset structure on capital structure and company size of manufacturing company. However, for mining company, the asset growth and profitability have a negative and insignificant effect of capital structure [4]. In this context, Shaw and Rakshit [24] by their research of non-financial firm listed in Indian Stock Exchange finds profitability, growth uniqueness, and age, follow pecking order theory, while size, tangibility, liquidity, GDP Growth, and inflation follow trade-off theory.

From above description the research hypothesis is:

HA1: It is predicted that the company's long-term debt moderates the effect of fixed assets on the company's capital structure.

\subsubsection{The Effect of Earning Per Share on Capital Structure}

The EPS has been calculated against market factors, namely the balance of risk and return. The estimated risk is directly proportional to the expected rate of return. Low risk estimation causes investors to expect low returns and ultimately the cost of equity capital will decrease [19].

When there is a positive perception from investors about debt, the return tends to be low, which means that the cost of capital is low. If so, then it has a positive effect on the company's capital structure. Conversely, if there is a negative perception from investors on debt, the return tends to be high, which means that the cost of capital is high. The consequence, it will have a negative effect on the company's capital structure.

The EPS naturally becomes a concern for shareholders and management [9]. As a result of activity in the market, EPS reflects the ability per share to generate profits for the company. EPS is calculated after dividends, so this benchmark is different from net income.

Based on the above statement, the research can present the following hypothesis

HA1: It is suspected that Earning per Share has a significant influence on the company's capital structure. This influence is predicted to be moderated by long term debt.

\subsubsection{The Effect of Net Income on Capital Structure}

The higher net income reflects the higher the company's income. Thus, there is an alternative for companies to set aside profits to be reinvested in the company, so that there are opportunities for additional capital.

The level of profitability of a company is one of the factors considered in the capital structure policy. Brigham and Gapenski [1] say that the companies with high returns frequently tend to use debt. But companies with low rates of return tend to use large debt to finance company activities. The recent research which links profitability to capital structure policies in automotive company indicates the absence of its effect on capital structure [7]. However, another research shows the positive and significant effect of profitability on capital structure [18]

If net income increases, there is an opportunity to increase the company's capital structure, but the company also has the opportunity to make loans. When the company borrows, part of the income is reduced due to debt installments, thereby negatively affecting the company's capital structure.

From this description, the following research hypotheses can be proposed:

HA1: It is predicted that Net Income has a significant influence on the company's capital structure. This influence is moderated by long term debt.

\section{Material and Methods}

This research adopts a quantitative approach and uses descriptive-associative method. The descriptive method serves to describe or provide an overview of the object of study through the applicable sample or population data. The associative method is used to determine how the influence of the independent variable on the dependent variable; and how far the variation of the dependent variable can be explained by the variation of the independent variables.

\subsection{Population and Sample}

The research population includes 34 of manufacturing companies that issue their shares (Initial Public Offering) on the Indonesia Stock Exchange for the period of 2018 to 2020. The sample of this research is determined purposively based on following criteria: (a) has published the annual financial statement at the end of year which the company conducts the IPO process; and (b) has been issued the complete data in accordance with the need of this research. Based on this criterion, this research has gained 11 companies from 2018 period, 9 companies from the 2019 period, and 12 companies from 2020 period. Thus, the sample of this research is 32 manufacturing companies (Table 1). 
Table 1. The Sample of This Research

\begin{tabular}{|c|c|c|c|c|c|}
\hline No & $\begin{array}{c}\text { The IPO } \\
\text { Companies }\end{array}$ & $\begin{array}{c}\text { Years } \\
\mathbf{2 0 1 8}\end{array}$ & $\begin{array}{c}\text { Years } \\
\mathbf{2 0 1 9}\end{array}$ & $\begin{array}{c}\text { Years } \\
\mathbf{2 0 2 0}\end{array}$ & Total \\
\hline 1 & $\begin{array}{c}\text { The number of } \\
\text { IPO-companies }\end{array}$ & 11 & 11 & 12 & 34 \\
\hline 2 & $\begin{array}{c}\text { The } \\
\text { incomplete-data } \\
\text { company }\end{array}$ & - & 1 & - & $(1)$ \\
\hline 3 & $\begin{array}{c}\text { The outlier } \\
\text { company }\end{array}$ & - & 1 & - & $(1)$ \\
\hline & \multicolumn{4}{|c|}{ Total Sample } & 32 \\
\hline
\end{tabular}

\subsection{Data Collection}

Data collection is carried out through documentation and observation. In more detail, the source data of this research is the financial statements published at the end of the year, in which the companies conduct the IPO process, from 2018 to 2020 through www.idx.co.id. For the companies that carried out the IPO process in 2018, this research collects the financial statement of 2018. Likewise, for companies that conduct IPOs in 2019, the data for this research are 2019 financial reports; and this research finally collect the data of 2020 financial report for the companies that perform the IPOs in 2020.

\subsection{Variable Measurement}

As secondary data taken from the company's financial statements, the measurement follows the format according to the quantitative data in the company's financial statements. Capital structure as the dependent variable is operationalized by using equity because the discussion in this study is more focused on the process of IPO shares in the capital market.

Meanwhile, some independent variables of this research are: (1) corporate debt, (2) company asset, (3) Earning per share, and (4) Net income at the year that the companies conduct the IPOs, which is operationally defined as follows:

(a) Corporate debt is the company's Long-Term Debt that is the responsibility of the IPO- manufacturing companies;

(b) Company assets are fixed assets owned by the IPO-companies;

(c) The Earning per Share (EPS) is the EPS obtained by the IPO-companies;

(d) Net income is the income before the distribution of dividends to shareholders of IPO companies;

\subsection{Data Analysis}

In accordance with the research purpose and to provide an overview of the research results, this study applies descriptive statistics to provide an overview of the research variables independently, which is assisted by graphical visualization. The next stage, this research adopts the multiple regression model analysis with cross section data from the year of 2018, 2019 and 2020, with following equation:

$$
\begin{array}{cc}
\mathrm{Y}=\alpha+\beta_{1} \mathrm{X}_{1}+\beta_{2} \mathrm{X}_{2}+\beta_{3} \mathrm{X}_{3}+\beta_{4} \mathrm{X}_{4} & \operatorname{model}(1) \\
\mathrm{Y}=\alpha+\beta_{1} \mathrm{X}_{1}+\beta_{2} \mathrm{X}_{2}+\beta_{3} \mathrm{X}_{3}+\beta_{4} \mathrm{X}_{4}+\beta_{5} \mathrm{M}_{\mathrm{o}} \\
+\beta_{6} \mathrm{M}_{1}+\beta_{7} \mathrm{M}_{2} . & \operatorname{model}(2)
\end{array}
$$

Where:

$\mathrm{Y}=$ Equity $\quad \mathrm{X}_{4}=\quad$ Long Term Debt

$\mathrm{X}_{1}=$ Net Income $\quad \mathrm{M}_{\mathrm{o}}=\quad$ Moderation Variable 1

$\mathrm{X}_{2}=$ Earnings per $\quad \mathrm{M}_{1}=\quad$ Moderation Variable 2

$\mathrm{X}_{3}=$ Fixed Asset $\quad \mathrm{M}_{2}=\quad$ Moderation Variable 3

$\alpha$ is a constant

$\beta_{1}, \beta_{2}, \beta_{3}$, and $\beta_{4}$ are regression coefficients

To test the hypothesis, the researcher use of $5 \%$ of $\alpha$ (alpha). The t-test as a hypothesis testing tool is applied by following criteria. If the probability value is less than $5 \%$, it can be said that statistically very significant; and if the probability value is more than $5 \%$ but less than $10 \%$, it can be said that statistically is significant. For the F-test to prove the simultaneous effect of four independent variables to the dependent variable, this research also applies the same criterion.

\section{Result and Discussion}

\subsection{Description of Equity and Company Long Term Debt}

The IPO is one of the ways to meet the company's funding needs. The process is quite time consuming, but when it is successful, the company will obtain fresh funds large enough so that it has a significant effect on meeting its investment needs. With the success of the IPO, the company's credibility in the eyes of the public is also getting better.

Descriptively, in Figure 2, it can be seen that the average level of equity of manufacturing companies that have gone public has increased in 2019. Referring to data provided in Figure 2, there is a downward trend of equity from 2018 period to 2020 . For more detail, it appears that the average equity of manufacturing companies who perform the IPO in 2018 to 2020 is approximately 456.41 billion rupiah, with a standard deviation of 684.31 billion rupiah.

The fairly large standard deviation of the equity reflects the variation of value of the capital structure of manufacturing companies which is quite diverse. However, it is difficult to analyze the real equity of the company because the equity is more unique to each company. In detail, presented in Figure 3, as many as $25 \%$ of manufacturing companies have an equity above the average value of other companies, and the remaining of $75.00 \%$ (53.13\% plus $21.88 \%$ ) have the average value of the equity below or equal to the equity of other company. 
For more detail, $25 \%$ of sample of manufacturing companies have the equity value over 100 percent of average value of other manufacturing companies; $21.88 \%$ have equity between $50 \%-100 \%$ of the average of other companies; while the equities of the majority of sample $(53.13 \%)$ are under $50 \%$ of average value of equities. The IPO process could probably solve this critical condition of low equities; and of course will have a positive impact on obtaining fresh funds from the public, but the company ownership will change from private to public ownership.

The manufacturing process that takes a relatively long time will affect the company's operating cycle. The operating cycle is the time when funds are tied up from the time when the company purchases materials until the cash comes back into the company. It is clear that the operating cycle will differ depending on the type of company, for example a service company, trading or manufacturing company. The operating cycle of manufacturing companies is longer than service and trading companies. The longer the manufacturing process means the longer the company's funds are tied up, so the need for funds is also getting bigger. Thus, the attachment of investment funds to manufacturing companies will be greater [17].

This is one of the causes of the tendency of manufacturing companies to have large debts. Descriptively, Figure 4 presents the average debt level of publicly listed manufacturing companies which increased in 2019. The data presented in Figure 4 indicates the increase of debt compared to 2018. A slight decrease occurred in 2020, possibly due to the Covid-19 pandemic situation which resulted in the impact of not interesting debt. In the current situation, it is difficult for companies to increase capacity or expand their business to be able to survive. One of these negative impacts can be seen from the declining production process due to the reduction in working hours caused by the work-from-home phenomenon in almost all companies in Indonesia. In more detail, it can be seen that the average debt in 2018 to 2020 is approximately 233.51 billion rupiah, with a standard deviation of 400.85 billion rupiah.

About the comparison of long-term debt, it can refer to data provided in Figure 5, which shows, 75.01\% of the manufacturing companies who perform the IPO process have a maximum long-term debt under or equal to the average value. This can be interpreted that most companies are quite careful in managing their long-term debt so that they still follow the signs that the level of debt does not exceed the industry average. The manufacturing companies who have long debt over the industry's debt average value are merely $25 \%$. The rest of $15.65 \%$ of manufacturing company has average long debt between $50 \%-100 \%$ of industry's debt average value; and fortunately the majority of companies (59.38\%) have merely long-term debt below $50 \%$ of the average of industry's long-term debt (Figure 5). In the other hand, the groups of companies who have long term debt over the industry's deb average could be considered to have a good credibility because it has successfully carried out the IPO process.

In accordance with basic principle of prudence, this research finding indicates the IPO process from 2018 to 2020 was dominated by companies with long-term debt below the average value. It could be emphasized the manufacturing companies in Indonesia are actually still quite careful in controlling its external sources of funds. By using long-term debt funds, the company will be burdened by a fixed expense in the form of interest, although on the other hand it can be a leverage factor that can be utilized by the company. Thus, the long-term debt arouses the question about its role on the capital structure of manufacturing company especially indirectly through fixed asset.

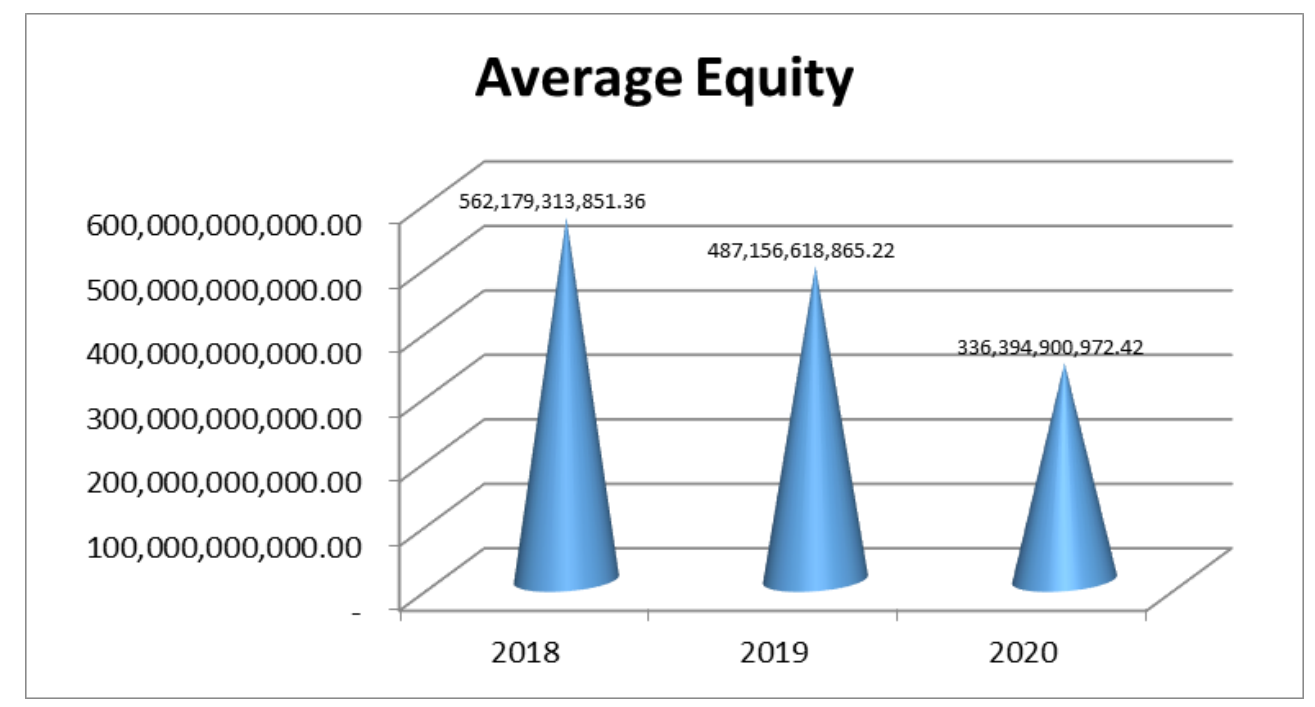

Figure 2. The Equity of Manufacturing Company in Billion Rupiah 


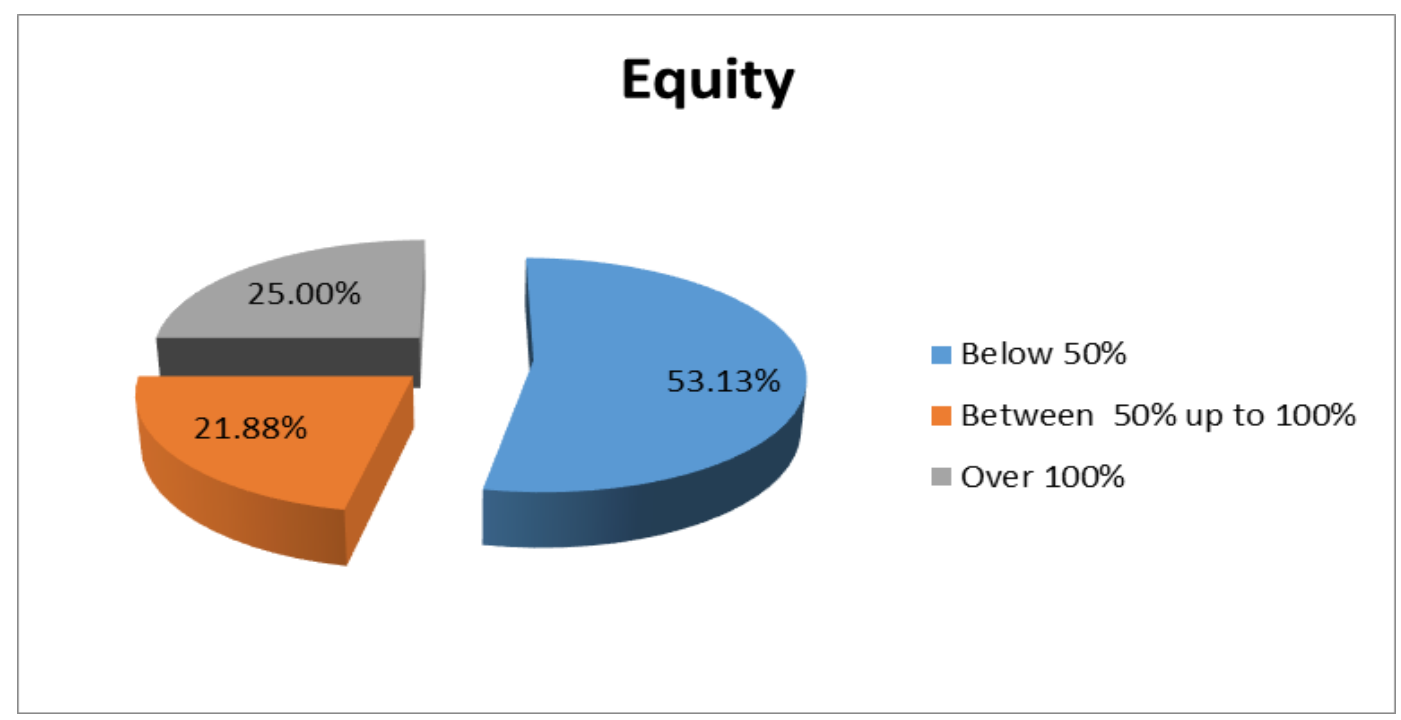

Figure 3. The Average of Equity Comparison Between Manufacture Company

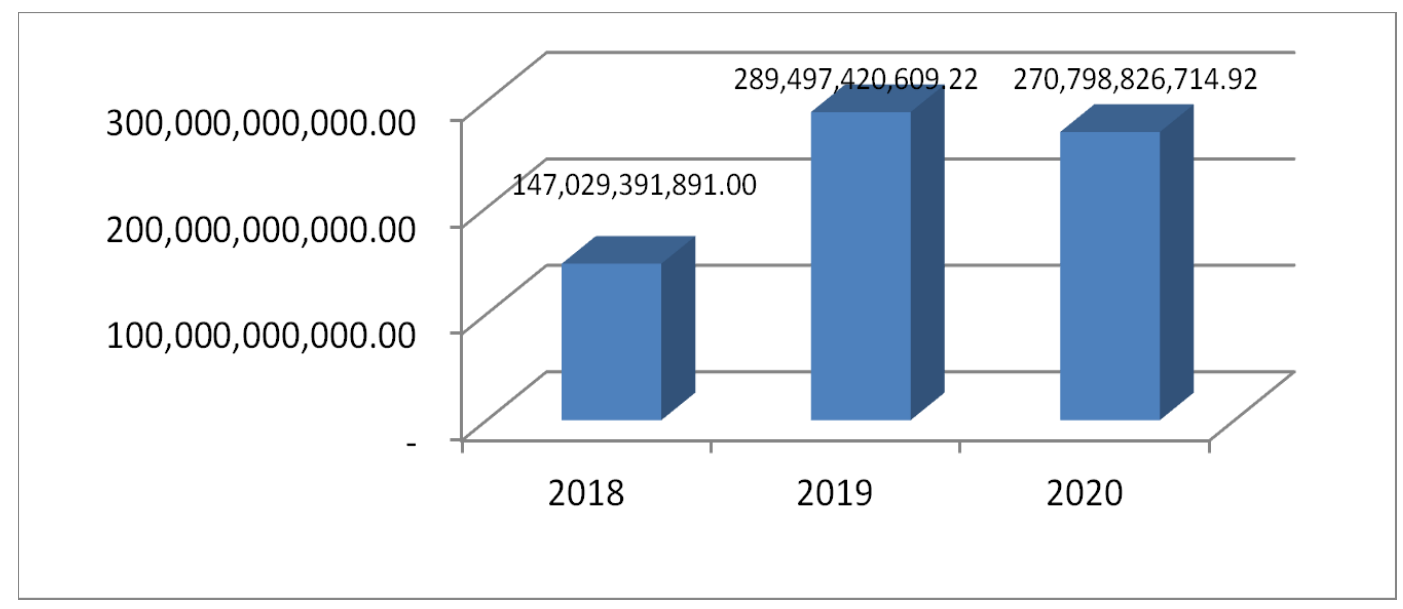

Figure 4. The Long-Term Debt of Company Manufacture

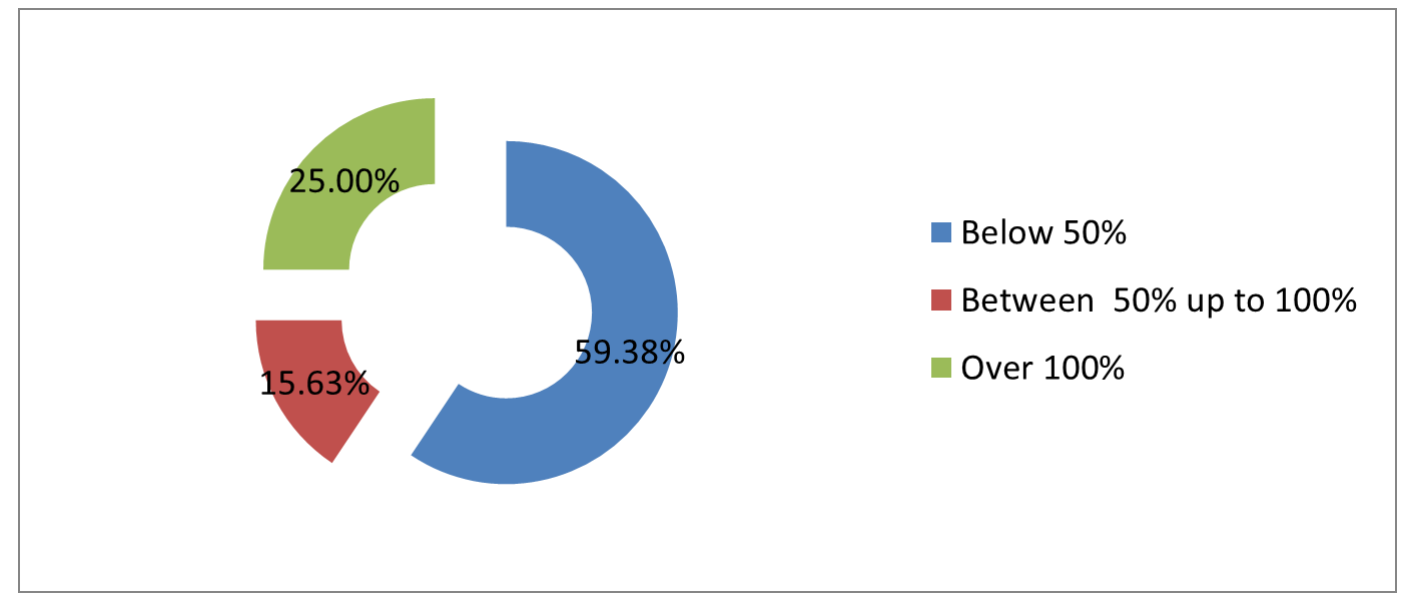

Figure 5. The Average of Long-Term Debt between Manufacture Companies

\subsection{Description of Manufacture Company Fixed Asset}

The sources of company funds can come from internal or external companies. The company should manage properly the source of funds, one of which is when the company determines to invest in the company's fixed assets. This is because one of benchmarks of the size of a company can be seen from the value of fixed assets, which for the 
manufacturing companies it can be in the form of factories with all operational standards and procedures (SOP) to support the smooth manufacturing process. The larger the company is the greater the investment in fixed assets. The following Figure 6 describes the level of debt and fixed assets of several companies that carried out the IPO process in 2018 to 2020. The manufacturing companies who perform the IPO process in 2018-2020 still adheres to the precautionary principle, indicated by the fluctuation between the fixed asset and the long-term debt. For several companies, the level of fixed asset and the long-term debt is not strongly different; but for several companies there is the tendency that the fixed asset is more than the long debt (Figure 6).

In addition, the results of this study illustrate that the average fixed asset of manufacturing companies in 2018 to 2020 is approximately 528.74 billion rupiah, with a standard deviation of 703.65 billion rupiah. A fairly large standard deviation indicates that the value of fixed assets is quite varied. The greater the company's fixed assets are identical to the greater the investment so that the opportunity to earn profit is also greater.
In more detail about the comparison between fixed asset and average long-term debt, it is quite clear by data presented in Figure 7. It is valuable to present that $28.13 \%$ of manufacturing companies have fixed assets above $100 \%$ of the average value of manufacturing companies. This finding indicates strongly that this group of company has investments that exceed the investment capacity of manufacturing companies' fixed assets. For these companies, the opportunity to make a profit is of course getting bigger because the gaining debt depends upon the number of fixed asset owned by the companies that could become a collateral. The consequence, the larger the company's fixed assets, the more likely it is to obtain debt guaranteed by the fixed assets.

However, referring to the data presented in Figure 7, this "good privilege" is merely owned by a small number of manufacturing companies. The majority of them $(53.13 \%)$ have merely fixed asset below $50 \%$ of average values of manufacturing company. The rest of the companies (18.75\%) have better fixed asset, namely between $50 \%$ up to $100 \%$ of average value of company's fixed asset.

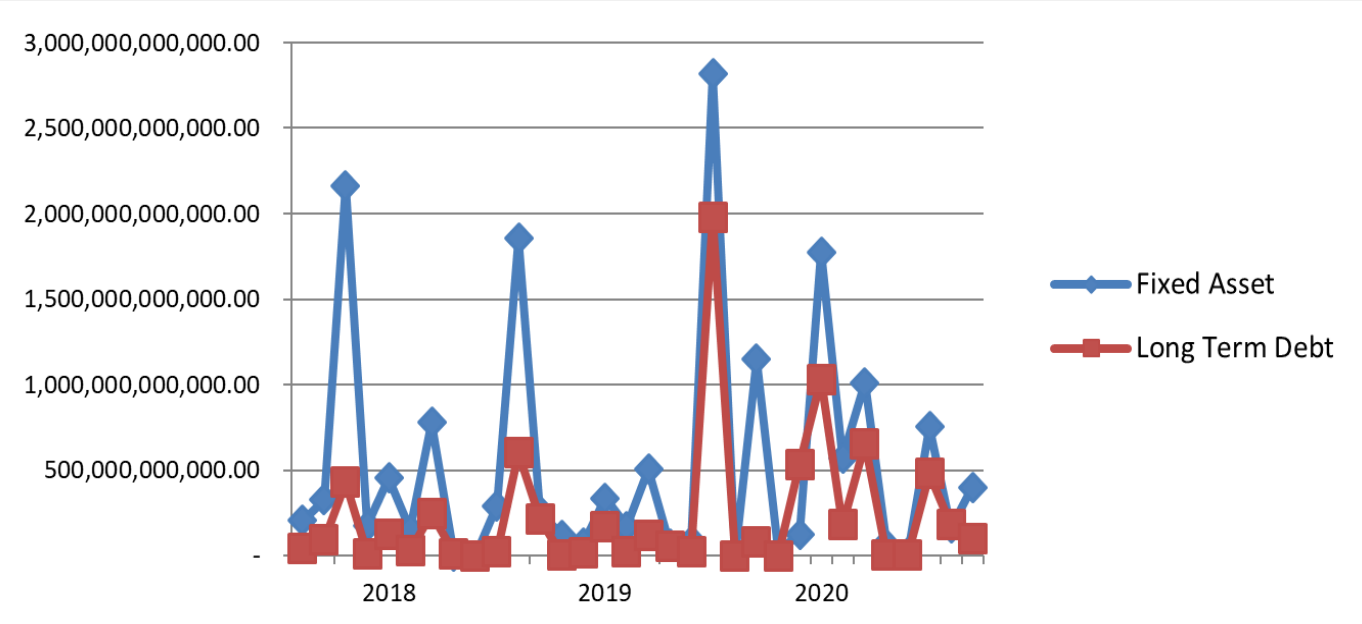

Figure 6. The Long-Term Debt and Fixed Asset

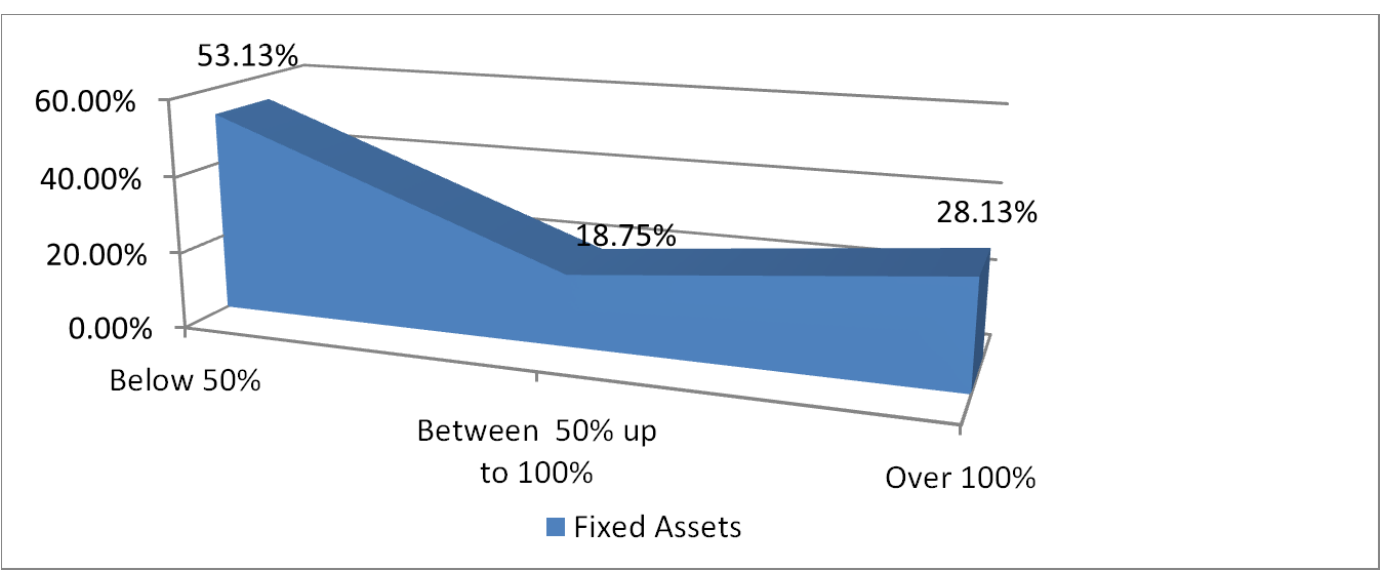

Figure 7. The Average of Fixed Asset of Manufacture Company 


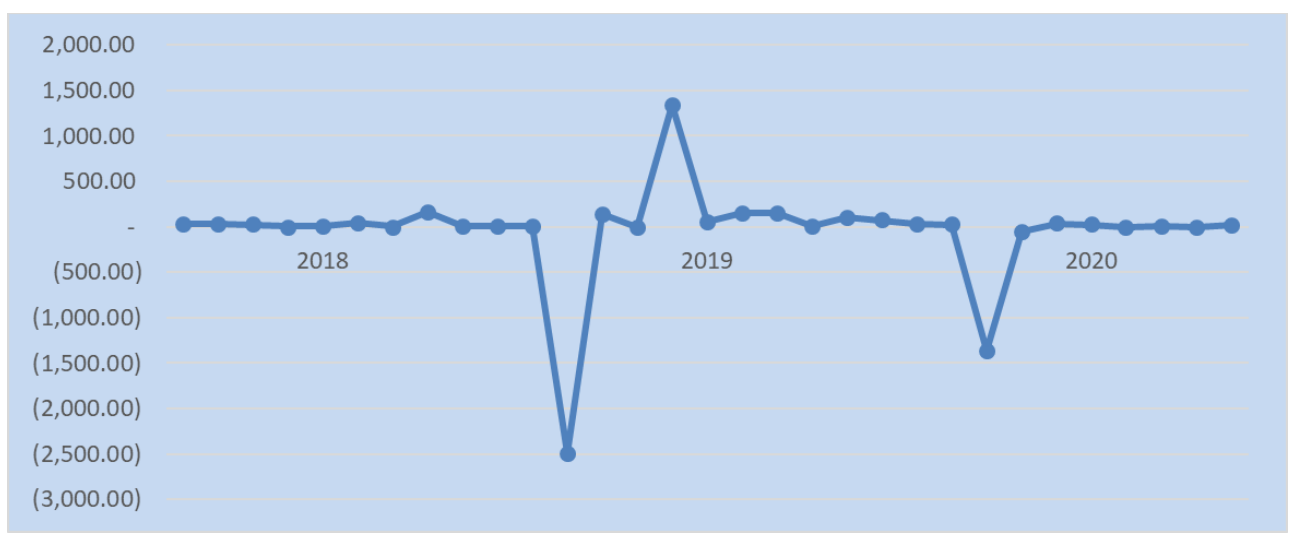

Figure 8. The Earning Per Share of Manufacture Company

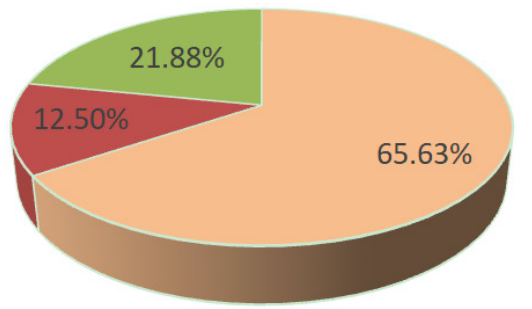

- Below 50\%

- Between $50 \%$ up to $100 \%$

- Over $100 \%$

Figure 9. The Average of Net Income of Manufacture Company

\subsection{Description of EPS and NI of Manufacture Company}

The Earning per Share (EPS) is the income for an accounting period divided by the number of outstanding shares. The higher the EPS value is the greater the company's profits, and vice versa. The EPS data for manufacturing companies that perform IPO in the period 2018 to 2020 show a fairly volatile value (Figure 8 ). More specifically, there are two companies with negative EPS values, while there is a company with very high EPS values. Nevertheless, descriptively it appears that the majority of EPS values of manufacturing company are still positive, which is quite interesting.

Regarding the Net Income (NI) of manufacturing companies, it is important to describe that in 2018 to 2020 its average value shows approximately 64.45 billion rupiah, with a standard deviation of 142.61 billion rupiah. The Net income is the profit earned by the company after all operating costs are removed

The picture of net income can be seen in Figure 9. It is quietly clear that $21.88 \%$ of the companies have net income above the average value, which means that this group of companies gain a net profit exceeds manufacturing companies in general. On the other hand, $65.63 \%$ of the companies have a net income below the average value of manufacturing companies in general. However, although the majority of companies have a net income below the average value, but it should be noted the net income already includes the company's operating costs so that the operation of the companies is relatively safer.

\subsection{The Simultaneous and Partial Effect on Equity}

As it is known that the purpose of this study is to identify the moderating effect of long-term debt on the company's capital structure. For this purpose, this study presents two test models. The first model is the result of multiple linear regression testing regarding the effect of net income (NI), earnings per share (EPS), fixed assets (FA), and long-term debt (LTD) partially (with t test) and also in total with R-square analysis. The second model, in addition to presenting the effect of each of variables, also presents the interaction or moderation effect (Mo) between LTD, NI, EPS, and FA and their effect on equity.

But previously this research performs the autocorrelation test to gain a qualified research data. Fortunately, the Durbin Watson test which is adopted in this research indicates, by $5 \%$ of alpha level and $n=32$, the value of $d_{L}$ is 1.11 and $d_{U}$ is 1.82 , and therefore the value of $4-d_{U}$ is 2.18 and the value of $4-d_{L}$ is 2.99 . Thus, the first model of this research gets the absence of autocorrelation because the DW test is 1.976 , takes position between $1,82<$ $1,976<2,18$. The DW test in the second model of linier regression gets also the non-autocorrelation, because it takes also the position between $d_{U}$ and $4-d_{U}$ or between $1,82<2,015<2,18$; which indicates that the two of 
multiple regression models do not have autocorrelation, and therefore the model is suitable to apply in this test (Table 2).

The output of the first and second model shows that the F test statistically has a significant effect on dependent variables with the error probability value is 0.000 , which indicates that all variables (NI, EPS, FA, and LTD) simultaneously have a very significant effect on the equity of the manufacturing company (Table 2).

Table 2. F Test and Durbin Watson Test

\begin{tabular}{|c|c|c|}
\hline Model & Probability Value (F test) & Durbin Watson \\
\hline Model I & $\left.0.000^{*}\right)$ & $\left.1.976^{* *}\right)$ \\
\hline Model II & $\left.0.000^{*}\right)$ & $\left.2.015^{* *}\right)$ \\
\hline
\end{tabular}

Significant at $5 \%$.

No autocorrelation

However, for more detail, the t test in the first model (which are presented in Table 3) shows that LTD does not have a significant effect on the company's capital structure because the error probability value is more than five percent (the alpha is above 5\%). The variables that have significant effect (based on t-test) on equity are net income, fixed assets, and the earning per share. These variables have error probability value less than five percent (the alpha is below 5\%).

However, in contrast to the first model, in the second model the variable which has a significant effect on the capital structure is merely a fixed asset because this variable based on the $t$ test has an error probability value less than five percent. The net income has actually the error probability value less than ten percent (Table 4), but this research rejects the Ho based on the criteria that the t test result should have error probability less than five percent. Thus, this research concludes the net income does not influence of the equity in the second model.

In addition to above research finding, the second model provides the important result of this research which is highly relevant with the purposes of this research. The valuable result is, the second model statistically proves the existence of moderation effect of LTD on the equity.

It should also be emphasized that the first model provides the R-square of 0.881 or $88.10 \%$, which means that the variation of the four independent variables presented in first model is able to explain $88.10 \%$ of equity variables, while the remaining of $11.90 \%$ is explained by other variables. The R-square value has increased in model 2 , from 0.881 to 0.928 or $92.80 \%$ (Table 5 ), which strongly indicates that the LTD contributes the effect of four variables to the equity of manufacturing company.

Table 3. The Partial Effect of Four Variables on Equity

\begin{tabular}{|c|c|c|c|c|c|c|c|c|}
\hline \multicolumn{9}{|c|}{ Coefficients } \\
\hline & \multirow{2}{*}{ Model } & \multicolumn{2}{|c|}{ Unstandardized Coefficients } & \multirow{2}{*}{$\begin{array}{c}\text { Standardized } \\
\text { Coefficients }\end{array}$} & \multirow[t]{2}{*}{$\mathbf{t}$} & \multirow[t]{2}{*}{ Sig. } & \multicolumn{2}{|c|}{ Collinearity Statistics } \\
\hline & & $\mathrm{B}$ & Std. Error & & & & Tolerance & VIF \\
\hline \multirow{5}{*}{1} & (Constant) & -1103226537.507 & 56580075862.182 & & -.019 & .985 & & \\
\hline & NI & -1.019 & .441 & -.212 & -2.313 & .029 & .522 & 1.914 \\
\hline & EPS & -151516.578 & 62620.709 & -.168 & -2.420 & .023 & .911 & 1.098 \\
\hline & FA & .853 & .123 & .877 & 6.911 & .000 & .273 & 3.657 \\
\hline & LTD & .398 & .219 & .233 & 1.818 & .080 & .267 & 3.741 \\
\hline
\end{tabular}

Table 4. The Moderation Effect of LTD on Equity

\begin{tabular}{|c|c|c|c|c|c|c|c|c|}
\hline \multicolumn{9}{|c|}{ Coefficients $^{\mathrm{a}}$} \\
\hline & \multirow{2}{*}{ Model } & \multicolumn{2}{|c|}{ Unstandardized Coefficients } & \multirow{2}{*}{$\begin{array}{c}\begin{array}{c}\text { Standardized } \\
\text { Coefficients }\end{array} \\
\text { Beta }\end{array}$} & \multirow[t]{2}{*}{$\mathbf{t}$} & \multirow[t]{2}{*}{ Sig. } & \multicolumn{2}{|c|}{ Collinearity Statistics } \\
\hline & & B & Std. Error & & & & Tolerance & VIF \\
\hline \multirow{8}{*}{1} & (Constant) & 19318885177.916 & 55512190041.946 & & .348 & .731 & & \\
\hline & NI & 1.430 & .739 & .298 & 1.935 & .065 & .126 & 7.923 \\
\hline & EPS & -232855.804 & 2195108.546 & -.259 & -.106 & .916 & .001 & 1983.986 \\
\hline & FA & .617 & .118 & .634 & 5.224 & .000 & .203 & 4.920 \\
\hline & LTD & .147 & .347 & .086 & .423 & .676 & .072 & 13.805 \\
\hline & Mo & $4.780 \mathrm{E}-13$ & .000 & .723 & 3.316 & .003 & .063 & 15.869 \\
\hline & M1 & $1.456 \mathrm{E}-7$ & .000 & .106 & .043 & .966 & .001 & 1988.627 \\
\hline & M2 & $-3.275 \mathrm{E}-12$ & .000 & -.786 & -3.633 & .001 & .064 & 15.626 \\
\hline \multicolumn{9}{|c|}{ a. Dependent Variable: Equity } \\
\hline
\end{tabular}


Table 5. The Beta Coefficient in the First and Second Model (5\% of Alpha)

\begin{tabular}{|c|c|c|c|c|c|c|c|}
\hline \multicolumn{2}{|c|}{ Model I } & \multicolumn{5}{c|}{ Model II } & Notes \\
\hline \multicolumn{2}{|c|}{0.881} & \multicolumn{5}{c|}{0.928} & R Square \\
\hline $\begin{array}{c}\text { Independent } \\
\text { Variable }\end{array}$ & Prob Value & $\begin{array}{c}\text { Independent } \\
\text { Variable }\end{array}$ & Prob Value & Independent Variable & Prob Value & \\
\hline FA & $\left.0.000^{*}\right)$ & FA & $\left.0.000^{*}\right)$ & $\mathrm{M}_{0}$ & LTD*FA & $\left.0.003^{*}\right)$ & Quasi Moderate \\
\hline EPS & $\left.0.023^{*}\right)$ & EPS & 0.916 & $\mathrm{M}_{2}$ & LTD*EPS & 0.966 & Pure Moderate \\
\hline NI & $\left.0.029^{*}\right)$ & NI & 0.065 & $\mathrm{M}_{1}$ & LTD*NI & $0.001 *)$ & \\
\hline LTD & 0.080 & LTD & 0.676 & & & & \\
\hline
\end{tabular}

*) Significant at $5 \%$

\subsection{The Effect of FA and LTD on Equity}

The first hypothesis in this study is the assumption that fixed assets have a significant effect on the company's capital structure, and are moderated by long term debt. The fixed assets variable in the first model is proven to have a significant effect on the company's capital structure with an error probability value of 0.000 (the alpha is less than $5 \%$ ). It is clear that the first hypothesis is proven true, which there is a positive influence of asset growth and capital structure.

In addition, the Mo variable which is the result of the interaction between LTD and FA in model 2 has a significant effect on the company's capital structure with an error probability value of 0.003 . This clearly indicates that the interaction between long-term debt and the company's fixed assets has a significant effect on the equity of a manufacturing company. This is reinforced by the increase of the R-square value from 0.881 or $88.10 \%$ in model 1 to 0.928 or $92.80 \%$ in model 2 . This research finding has reminded us the classic research conducted by Jogiyanto which shows the interaction between debt and fixed asset and its influence on the capital structure [12].

In more detail, referring to data presented in Table 5, the result of this research illustrates that the long-term debt takes the position of quasi-moderator between the effects of fixed assets on equity. Based on this finding, it is clear that the first hypothesis of this research is proven correct. Thus, good debt management can increase the company's capital structure, and can increase the company's opportunities to earn more profits.

\subsection{The Effect of EPS and LTD on Equity}

The second hypothesis in this study is that the Earning per Share (EPS) is assumed to have a significant influence on the company's capital structure. Fortunately, the result of the study shows the expected results based on the criteria that the probability value is 0.023 (less than $5 \%$ of alpha), so it can be concluded that there is a significant effect of EPS on the capital structure. However, the further analysis which places the LTD as the moderator variable, it turns out that the LTD does not moderate the effect of EPS on the capital structure of manufacturing company.

This conclusion is based on the criteria that the effect of
M2 variable -- which is the result of interaction between EPS and LTD - to the equity has 0.966 of error probability value (Table 5). It means that if we conclude the LTD as a moderator variable between the effects of EPS on the equity, the conclusion has 96 percent of error chance, or even close to 100 percent of error probability. Thus, this research finds that the EPS is an important factor for the development of the company's capital structure, but the interaction between LTD and EPS is not an important factor to develop the equity of manufacturing company.

\subsection{The Effect of NI and LTD to the Equity}

The third hypothesis of this study predicts that the Net Income has a significant influence on the company's capital structure. This assumption is proved accepted based on the test in the first as well as in the second model. The first model presents the 0.029 error probability, and this p-value proves decreases in the second model of multiple regression test, from 0.029 to 0.001 ; and the both error probabilities are bellow five percent as an expected value.

The further test which questions whether this effect is moderated by Long Term Debt, the result also shows that the LTD is a pure moderator between the effects of NI on the equity of manufacturing company. For more detail, the data presented in Table 5 indicates that the M1 - which the result of interaction between NI and LTD - has error probability 0.001 which can be concluded that the LTD moderates purely the effect of NI on the equity of manufacturing industry.

The results of this study are in line with the results of research conducted by Siti Mujiatun et al [18]- in the light of sharia-based manufacturing company who listed on the Indonesian Stock Exchange in the period of 2016 - 2019 which indicates the significant effect of asset structure and profitability on the capital structure. However, about the effect of LTD on equity, the Mujiatun's research does not present it, because in the shariah's perspective the interest-based debt - the short as well as the long term - is unlawful. Therefore, the next research should focus on this concern.

From the above hypothesis and research finding, it is clear by referring to Viktoriya and Marianna [23], the importance of financial controlling framework, which 
includes determination of economic contents, classification of the type, form, and methods of financial controlling. For more specific, it needs the framework of long-debt control by making the best use of the debt for investment in fixed assets.

\section{Conclusions and Recommendation}

- Descriptively, it is known that the average equity of manufacturing companies that carried out the IPO process in 2018-2020 is approximately 18,585 billion rupiah, with a standard deviation of 73.717 billion rupiah. The fairly large standard deviation reflects the variation in the equity value of manufacturing companies which is quite diverse. This shows that the value of equity is a unique factor for each company.

- Most of the manufacturing companies that carried out the IPO process in 2018-2020 are dominated by companies that have long-term debt below the average value of the company's long-term debt. Therefore, companies that carry out the IPO process between 2018-2020 can be considered to be still quite careful in controlling their external sources of funds, namely long term debt with an indication that the company's average debt is still below the industry average debt level.

- The results of statistical tests show that the net income, fixed assets, and the earning per share have a significant effect on the company's capital structure; while the long-term debt do not have a significant effect on the capital structure of manufacturing companies.

- The long-term debt significantly quasi moderates the effect of fixed assets on the company's capital structure. However, the long-term debt significantly pure moderates the effect of the net income on the company's capital structure

- For this reason, this study suggests: (a) companies should pay attention to the net income and the fixed assets in increasing the company's capital structure; and (b) manufacturing companies need to increase the effectiveness of long-term debt management in optimizing the company's capital structure to gain profits.

\section{REFERENCES}

[1] Agus S., "Long Term Financing Decision: Views and Practices of Financial Managers of Listed Public Firms in Indonesia," Gadjah Mada International Journal of Business, vol. 3, no. 1, pp. 35-44. 2001, https://www.sema nticscholar.org/paper/Long-Term-Financing-Decisions $\% 3$ AViews-and-Practices-Sartono/5bacf7b2595934bc833f005 377e5780374b0c267\#paper-header
[2] Ahmad C. N., M. Firdaus, T.A. Andati, and T. Irawan, "Investment Decision in the Agency Theory Framework," MIX: Jurnal Ilmiah Manajemen, vol. 7, no. 1, pp. 16-32, 2018, DOI: dx.doi.org/10.22441/mix.2018. v8i1.002

[3] Alper V. C., B. Tosunoglu, E. Gürtay, "The Role of Financial Ratios to Determine the Value of Stock : A Application in Bist," European Conference On Social and Behavioral Sciences, Belgrade, Serbia, 2015, pp. 1-14, https://www.academia.edu/28734972/THE_ROLE_OF_FI NANCIAL RATIOS TO DETERMINE THE VALUE OF_STOCK_AA_APPL̄ICĀTION_IN_BIST

[4] Ipon S., Candrianto, M.A. Gusti, E. Juniardi, and M. Novenica, "Analysis of the Effect of Asset Growth, Profitability, and Company Size on Capital Structure: Empirical Study in Mining Sector Companies in Indonesia Stock Exchange," Third International Conference on Economics Education, Economics, Business and Management, Accounting and Entrepreneurship in Advances in Economics, Business and Management Research, vol. 97, pp. 85-92, Published by Atlantis Press, 2019, DOI: https://doi.org/10.2991/piceeba-19.2019.10

[5] Brian L. Connelly, S. Trevis C., R.D. Ireland, and C. R. Reutzel, "Signaling Theory: A Review and Assessment," Journal of Management, vol. 37, no. 1, pp. 39-67, 2011, DOI: $10.1177 / 0149206310388419$

[6] Ela M., I. Muda, G.M. Nasir. "Effects of Capital Structure and Profitability on Corporate Value with Company Size as the Moderating Variable of Manufacturing Companies Listed on Indonesia Stock Exchange," Academic Journal of Economic Studies, vol. 2, no.3, pp. 30-43, 2016, http://www.ajes.ro/wp-content/uploads/AJES_article_1_64 .pdf

[7] Elta A., and Yuliadi, "Pengaruh Profitabilitas, Peluang Pertumbuhan dan Likuditas Terhadap Struktur Modal Perusahaan di Bursa Efek Indonesia," [The Effect of Profitability, Growth Probability and Liquidity of Capital Structure in Indonesian Stock Exchange], International Journal of Management and Business, vol. 1, no. 1, pp. 1-17, 2020, https://ijtvet.com/index.php/ijmb/article/view/4/7

[8] Endang K.P., N. Priyono, L.R. Indrawati. Analisis Ekuitas Terhadap Penentuan Pendanaan Utang Pada Perusahaan Manufaktur Di Indonesia Studi Kasus Perusahaan Mempublik Di Bej Periode 2008-2012. vol. 40, no. 2. I5, 2014, pp. 1-19; https://media.neliti.com/media/publication s/17763-ID-analisis-ekuitas-terhadap-penentuan-pendanaa n-utang-pada-perusahaan-manufaktur-d.pdf

[9] Gitman, Lawrence J., Zutter, Chad J. Principles of Managerial Finance. $3^{\text {th }}$ ed. Prentice Hall, 2012

[10] Hilma F. A., Irene R.D.P., and S.T. Raharjo, "The Effect of Asset Structure, Profitability, Company Size, and Company Growth on Capital Structure: The Study of Manufacturing Companies Listed on The IDX for The Period 2013 - 2017, Jurnal Bisnis STRATEGI, vol. 27, no. 2, pp. 123 - 136, 2018, https://ejournal.undip.ac.id/index.php/jbs/article/vie wFile/20826/14821

[11] Humera A.U. K., "Analysis of the Company's Financial Performance before and after the Company Conducts an Initial Public Offering," Proceedings of the International Conference on Culture Heritage, Education, Sustainable Tourism, and Innovation Technologies (CESIT), pp. 179-184, 2020; DOI: 10.5220/0010305801790184 
[12] Jogiyanto, H.M., "Model Empiris" [Empirical Model], Metodologi Penelitian Bisnis: Salah Kaprah dan Pengalaman-pengalaman [Research Method of Business: The common Wrong and Experience] Yogyakarta, Indonesia, BPFE, 2005, pp. 39-146

[13] Mahzen A., "Cost of IPOs, IPO dynamics in the short and long-run and value of textual tone of IPO prospectus," Doctoral Thesis of New York University, 2016; https://etheses.whiterose.ac.uk/16169/7/Thesis\%20V0.18 $\% 2031012017 . p d f$

[14] Mia O., S. Manalu, and S. Yuniarti, "Pecking Order and Trade-off Theory in Capital Structure Analysis of Family Firms in Indonesia," Jurnal Keuangan dan Perbankan, vol. 22, no. 1, pp. 73-82, 2018; http://jurnal.unmer.ac.id/index. $\mathrm{php} / \mathrm{jkdp}$

[15] Muhammad A. U., Syed A.J., Khaliqquzaman K., "Private Equity and its Role in the Development of the Indian Manufacturing Sector," International Journal of Economics and Financial Issues, vol 6, no 1, pp. 361-369, 2016; http://www.econjournals.com/index.php/ijefi/article/ view/1732/pdf

[16] Nana U., and Hashifah C. 2020, "Analisis Struktur Modal Berdasarkan Trade Off Theory [Analysis of Capital Structure Based on Trade Off Theory]," Jurnal Akuntansi : Kajian Ilmiah Akuntansi, vol 7, no. 1, 2020, pp. 52-70; https://doi.org/10.30656/jak.v7i1.1930

[17] Nusrat J., "An Empirical Investigation of Cash Conversion Cycle of Manufacturing Firms and its Association with Firm Size and Profitability," Bank Parikrama, vol 6, no. 2, pp. 18-32, 2011, https://arxiv.org/ftp/arxiv/papers/2005/20 05.09482.pdf

[18] Siti M., Rahmayati, and D. Ferina, "Effect of Profitability and Asset Structure on Capital Structure (In Sharia Based Manufacturing Companies in Indonesia Stock Exchange in 2016-2019 Period," Proceeding International Seminar on Islamic Studies, Medan, Indonesia, January 27-28, 2021, vol. 2, no. 1, http://jurnal.umsu.ac.id/index.php/insis/issue/ view/1232

[19] Sofia P.D.K., "Faktor-Faktor Yang Mempengaruhi Biaya
Modal Ekuitas Dengan Kepemilikan Manajerial Sebagai Variabel Moderasi [Factors Influences The Cost of Equity with the Managerial Ownership as a Moderations Variable]," Jurnal Akuntansi, vol. 19, no. 1, pp. 47-62, 2019, http://ejournal.ukrida.ac.id/ojs/index.php/akun/article/view $/ 1691 / 1771$

[20] Setia M., "The Benefits of Financial Ratios' as the Indicators of Future Bankruptcy on the Economic Crisis," International Journal of Nusantara Islam, vol. 03, no. 1, pp. $21-31,2015$, https://www.researchgate.net/publication/2 84750293_The_Benefits_of_Financial_Ratios'_as_the_Ind ocators_of_Future_Bankruptcy_on_the_Economic_Crisis

[21] Quiry, Pascal., Dallocchio, Maurizio., Le Fur, Yann., Vernimmen, Antonio., Salvi, Pierre. Corporate Finance: Theory and Practice John Wiley \& Sons Ltd, England, 2005.

[22] Ziad Mohammad Zurigat, "Financial Flexibility and The Speed of Target Adjustment of Capital Structure: Panel Data Analysis" Risk Governance \& Control: Financial Markets \& Institution, vol. 6, no. 4, pp. 410-419, 2016, https://doi.org/10.22495/rcgv6i4c3art6

[23] Viktoriya V.V., and Marianna A.S., "Theory for Financial Controlling in Corporations in the Modern Environment," Universal Journal of Accounting and Finance, vol. 9 no. 4, pp. 773-782, 2021. DOI: 10.13189/ujaf.2021.090423

[24] Sutanuka S. and Debdas R., "Determinants of Target Capital Structure and Adjustment Speed: Evidence from India." Universal Journal of Accounting and Finance, vol. 9, no. 2 , pp. 160-169, 2021. DOI: 10.13189/ujaf.2021.0902 03

[25] Trisninik Ratih Wulandari and Doddy Setiawan, "Capital structure manufacturing companies in Indonesia: In review," Jurnal Keuangan dan Perbankan, vol. 24, no. 4, 2020, pp. 485-493, http://jurnal.unmer.ac.id/index.php/jkdp

[26] D. Agus Harjito, "Teori Pecking Order dan Trade-Off dalam Analisis Struktur Modal di Bursa Efek Indonesia," [The Pecking Order Theory and Trade Off in Fund Structure Analysis in Indonesia Stock Exchange], Siasat Bisnis, Vol. 15, no. 2, 2011, pp. 187-19 